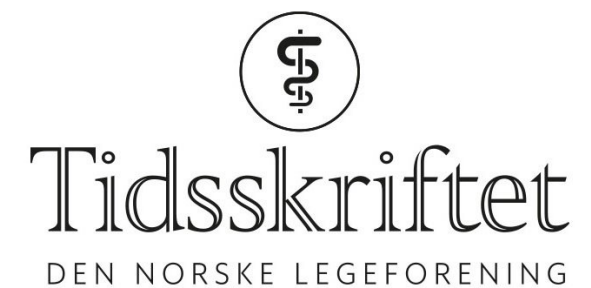

DEN NORSKE LEGEFORENING

\title{
Ja till ömsesidig respekt, men tyvärr nej till enighet
}

KOMMENTAR

\section{NIELS LYNØE}

E-post: niels.lynoe@ki.se

Niels Lynøe är allmänläkare och senior professor i medicinsk etik vid Karolinska institutet, Stockholm.

\section{ANDERS ERIKSSON}

Forfatterne oppgir følgende interessekonflikter: Anders Eriksson har de senaste tre åren skrivit flere expertutlåtanden i rättsliga förfaranden i samband med misstänkt barnmisshandel. Både författarna utgjorde tillsammans med fyra kollegor den expertgrupp som genomförde den systematiska litteraturgranskningen av «shaken baby syndrome».

Vi instämmer med Olav Haugen att vi bör ha respekt för varandras olika specialiteter och professionella integritet (1). Vi förstår att Haugens kommentarer utifrån hans långa erfarenhet inom barnoftalmologi kan ge intrycket av att vi som deltog i SBU-utredningen inte vet vad vi pratar om. Men, och detta är ett stort men, uppgiften för SBUs expertpanel i utredningen om skakvåld var att vi evidensgranskade den vetenskapliga litteraturen om skakvåld. Denna evidensgranskning förutsätter vetenskaplig skolning i kritisk granskning av vetenskapliga studier, däremot inte nödvändigtvis klinisk erfarenhet av de olika medicinska områden som berörs.

Vi delar inte Haugens uppfattning att vi felciterat Vinchon i hans svar till oss. Vinchon medger tvärtom att han fann det vetenskapligt problematiskt när han såg att specificiteten och det positiva prediktiva värdet blev (vetenskapligt orimliga) $100 \%(2)$. Anledningen till detta orimliga resultat var emellertid att Vinchon et al. hade tillämpat en helt annan triad bestående av diffusa retinala blödningar, subduralblödning samt frånvaroav yttre skador på huvudet (det vill säga isolerade dyadfynd). Anledningen till detta val var enligt Vinchon att antalet fall med hjärnpåverkan i deras studie var så få.

Vi vill påpeka att studien av Vinchon et al. var en av de två studier som SBU-rapporten lyfte fram som faktiskt hade strävat efter att undvika cirkelargumentation genom att utgå endast från fall där någon erkänt eller dömts för att ha skakat barnet (2). Det vill säga där det diagnostiska testet och referenstestet i princip skulle kunna antas att vara oberoende av varandra. De principiellt viktiga frågor vi ställde till Vinchon handlade om hur säker man kunde vara på att erkännandena var korrekta och huruvida representanter för barnskyddsteam hade vittnat i utredningen och i domstolen och därmed påverkat utfallet. Det var i detta sammanhang som Vinchon ansåg att vi inte hade anledning att ifrågasätta den metod de tillämpat. 
Haugen anser vidare att vi feltolkat Mulvihills undersökning om samstämmighet mellan bedömare där RetCam-bilder presenterades randomiserade och blindade (3). Vi kan bara konstatera att vi här är oeniga - vi anser faktiskt att en inter-bedömar-reliabilitet på endast o.219 innebär att bedömningarna är obetydligt bättre än slumpen. Enligt det använda Fleiss kappa-värdet innebär o.0-0.2 «slight», 0.21-0.4 «fair», 0.41-0.60 «moderate», o.61-0.8o «substantial» och o.81-1.0 «almost perfect inter-rateragreement». Ett kappa-värde på 0.219 är endast marginellt bättre än slumpen, och kan med självklarhet inte utgöra stöd för uppfattningen att vissa typer av retinala blödningar skulle vara patognomona för skakvåld en uppfattning som även the American Academy of Pediatrics och the American Academy of Ophthalmology sedan lång tid har lämnat (4).

Dubbelsidiga retinala blödningar är förknippade med ökat intrakraniellt tryck och är det som man ser vid hjärnsvullnad, som också har associerats med skakvåld. Men detta pekar också på ytterligare en aspekt av risken för bias i den vetenskapliga litteraturen om skakvåld; en kliniskt verksam ögonläkare gör inte sina undersökningar och bedömningar «blindad». Ögonläkaren har tvärtom i de flesta fall redan information om misstanken om skakvåld, något som knappast kan undgå att påverka observatörens bedömningar, och därmed ökar risken för bias ytterligare.

Till sist vill vi påpeka att vi inte påstått att förlossningsrelaterade subduralblödningar har liknande förlopp som förlossningsrelaterade retinala blödningar. Det finns olika uppgifter om hur länge en subduralblödning vanligen kan kvarstå - från en vecka upp till tre månader - samt att en sådan kan utvecklas till en kronisk subduralblödning med risk för symtomgivande reblödning. Med tanke på att förekomsten av påstått skakvåld har sin topp ca 8 veckor efter förlossningen $(5,6)$ kan observationen av både retinala blödningar och subduralblödning under de första tre levnadsmånaderna potentiellt komplicera bilden, dvs att förlossningsrelaterade fynd kan utgöra en differentialdiagnos till påstått skakvåld. Det vi påpekat är att de förlossningsrelaterade blödningarna förtjänar att bli föremål för närmare systematiska undersökningar $(7,8)$.

Vi är således helt överens om att man bör visa respekt inte endast för varandras olika specialiteter och professionella integritet, utan även måste citera litteraturen på ett korrekt sätt.

\section{LITTERATUR:}

1. Haugen OH. Netthinneblødninger og filleristede spedbarn. Tidsskr Nor Legeforen 2019; 139. doi: 10.4045/tidsskr.19.0196. [PubMed][CrossRef]

2. Vinchon M. Response to Lynøe: questions about isolated trauma shaking and confessions. Childs Nerv Syst 2017; 33:1423-4. [PubMed][CrossRef]

3. Mulvihill AO, Jones P, Tandon A et al. An inter-observer and intra-observer study of a classification of RetCam images of retinal haemorrhages in children. Br J Ophthalmol 2011; 95: 99-104. [PubMed][CrossRef]

4. Galaznik J. Postmortem orbital hemorrhage in the investigation of child abuse. Am J Forensic Med Pathol 2010;31: e7-9. [PubMed][CrossRef]

5. Parks SE, Kegler SR, Annest JL et al. Characteristics of fatal abusive head trauma among children in the USA: 2003-2007: an application of the CDC operational case definition to national vital statistics data. Inj Prev 2012; 18: 193-9. [PubMed][CrossRef]

6. Parks S, Sugerman D, Xu L et al. Characteristics of non-fatal abusive head trauma among children in the USA, 2003-2008: application of the CDC operational case definition to national hospital inpatient data. Inj Prev 2012; 18:392-8. [PubMed][CrossRef]

7. Lynøe N, Elinder G, Hallberg B et al. Insufficient evidence for 'shaken baby syndrome' - a systematic review. Acta Paediatr 2017; 106: 1021-7. [PubMed][CrossRef]

8. Lynøe N, Eriksson A. A diagnostic test can prove anything if you use incorrect assumptions and 
circular reasoning. Acta Paediatr 2018; 107: 2051-3. [PubMed][CrossRef]

Publisert: 7. oktober 2019. Tidsskr Nor Legeforen. DOI: 10.4045/tidsskr.19.0585

(C) Tidsskrift for Den norske legeforening 2020. Lastet ned fra tidsskriftet.no 